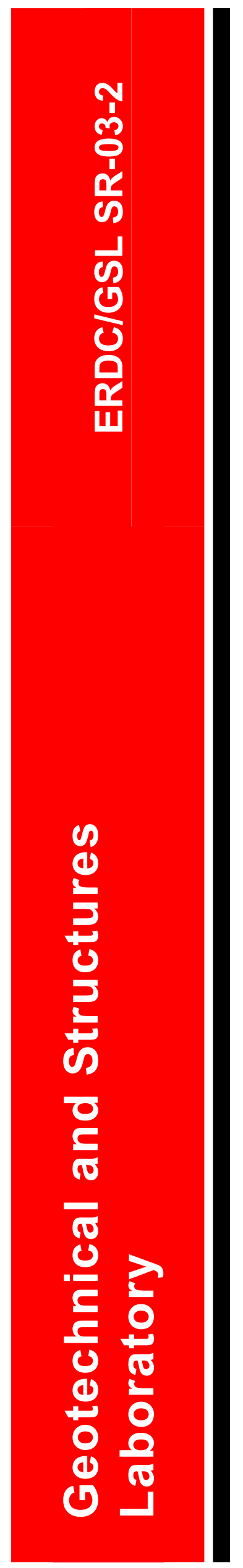

\title{
Evaluation of Runway Preservation System
}

James E. Shoenberger and J. Kent Newman

March 2003 
The contents of this report are not to be used for advertising, publication, or promotional purposes. Citation of trade names does not constitute an official endorsement or approval of the use of such commercial products.

The findings of this report are not to be construed as an official Department of the Army position, unless so designated by other authorized documents. 


\section{Evaluation of Runway Preservation System}

by James E. Shoenberger, J. Kent Newman

Geotechnical and Structures Laboratory

U.S. Army Engineer Research and Development Center 3909 Halls Ferry Road

Vicksburg, MS 39180-6199

Final report

Approved for public release; distribution is unlimited

Prepared for Asphalt Systems, Inc.

P.O. Box 25511

Salt Lake City, UT 84125 


\section{Contents}

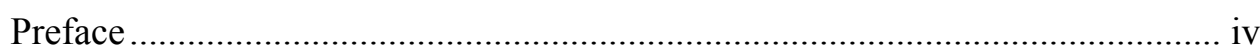

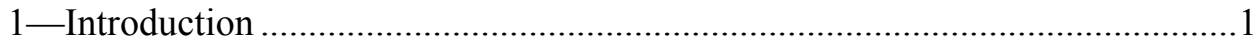

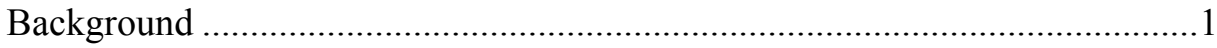

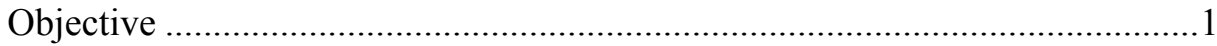

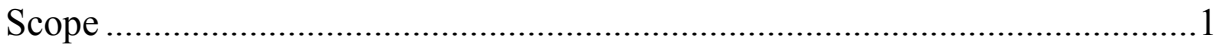

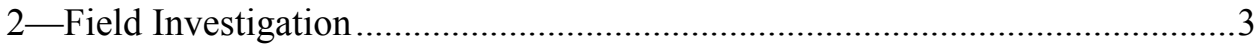

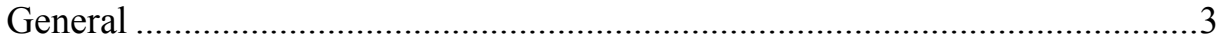

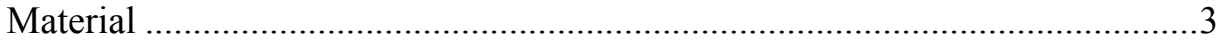

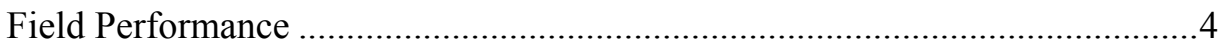

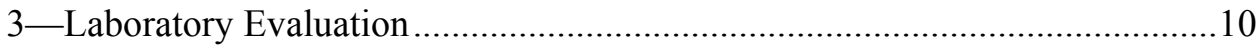

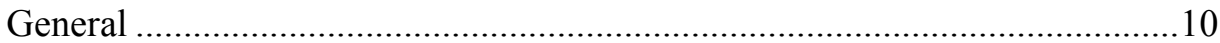

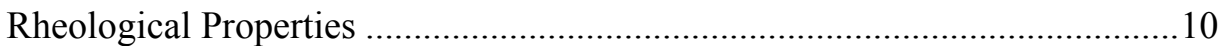

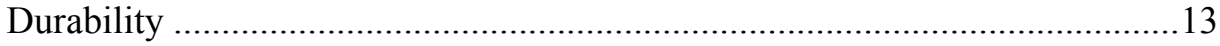

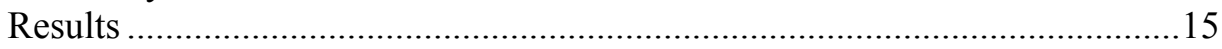

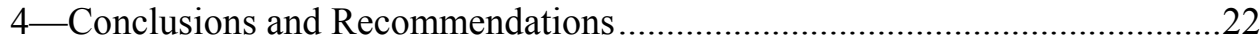

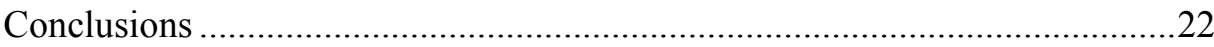

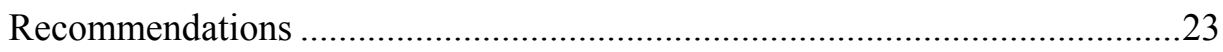

SF 298 


\section{Preface}

This report describes the results of field and laboratory evaluations conducted by the Geotechnical and Structures Laboratory (GSL), U.S. Army Engineering Research and Development Center (ERDC), Vicksburg, MS, for Asphalt Systems Incorporated, Salt Lake City, UT, under the Cooperative Research and Development Agreement, Army Control No. 9804-E-C243. The study was conducted from October 2000 to October 2001.

The study was conducted under the general supervision of Dr. David W. Pittman, Acting Director, GSL. Direct supervision was provided by Mr. Don R. Alexander, Chief, Airfields and Pavements Branch (APB). The principal investigators and authors for this project and report were Drs. James E. Shoenberger and J. Kent Newman, APB.

At the time of publication of this report, Dr. James R. Houston was Director of ERDC, and COL John W. Morris III, EN, was Commander and Executive Director..

The contents of this report are not to be used for advertising, publication, or promotional purposes. Citation of trade names does not constitute an official endorsement or approval of the use of such commercial products. 


\section{Introduction}

\section{Background}

The U.S. Air Force has a large number of bituminous airfield pavements. A major concern is increased susceptibility to raveling under traffic as the pavements age. Relative to this is the instance where a seldom-used airfield pavement suddenly receives an increase in traffic as the result of a change in mission requirements. Therefore, a material that could be easily and economically applied to aged pavement surfaces, to hold the existing surface structure in place, would be of great value.

Asphalt Systems Incorporated (ASI) has developed an emulsified bituminous product called Runway Preservation System (RPS). This material is intended as a pavement seal coat material for use on raveling airfield pavements. The pavement surface is normally sanded immediately after application of the emulsion. The ASI-RPS sealer has been successfully placed on over 60 general aviation airfields since 1990. It has been used at Portland International Airport (PDX), Portland, OR, since 1992. Tests at PDX and other locations have shown that the ASI-RPS does not have an adverse effect on skid resistance.

\section{Objective}

The overall objective of this research effort was to quantify, through field and laboratory testing, the various engineering characteristics required of ASIRPS to be an effective pavement sealer. The specific objective of the proposed work plan was to evaluate the effectiveness of the ASI-RPS as a sealer for airfield pavements on both low- and high-speed areas and its impact on pavement skid resistance.

\section{Scope}

The scope of this study was to evaluate the field performance of the ASI-RPS preventive maintenance system. Information on previous applications of the material and a site visit during placement would provide indications of the materials effectiveness. The laboratory portion of the test program evaluated the 
properties of the ASI-RPS residue and its impact on the existing binder and the ability of the residue to retain aggregate. The impact of the ASI-RPS on the existing binder was evaluated through coating and testing of Marshall specimens. The ability of the system to retain or hold aggregate was evaluated through the use of a scrub (abrasion) test. 


\section{Field Investigation}

\section{General}

The ASI-RPS has been used on over 60 general aviation airfields since 1990 . The material has also been used at PDX since 1992. Most of the applications have been on low-speed areas (roads, ramps, and taxiways) with few applications on the runways of general aviation airfields. Over 6 million square yards of pavement have been sealed with ASI-RPS. RPS has been used predominately throughout the western half of the United States in all types of climatic conditions. The manufacturer supplied a listing of eight different private, general-aviation, and military airfields that had used ASI-RPS on a repeat basis. The addition of sand to the treated surface for increased skid resistance in highspeed areas has been used since 1997.

\section{Material}

The RPS material is a cationic asphalt emulsion containing Gilsonite ore plus plasticizers. The as supplied RPS, in concentrated form, contains approximately 57 percent residue (after removal of the water). For application, the RPS material should be diluted with an equal amount of water. This product is intended specifically for seal coat applications where the existing surface pavement distress consists of loose or raveling aggregate particles. The product is designed to hold the surface together and extend the useful life of the pavement. This product has been produced since the early 1990s.

The following parameters should be considered during application. The cure time for the RPS emulsion will vary from 2 to $8 \mathrm{hr}$, depending on weather conditions. The temperature of the pavement surface should be a minimum of $13{ }^{\circ} \mathrm{C}$ $\left(55^{\circ} \mathrm{F}\right)$ and is forecast to be at this temperature or above throughout the curing period. RPS should not be applied to the pavement if it is wet or damp, rain is anticipated, or the wind velocity is judged to be too high for proper application.

The manufacturer of RPS also makes other sealer and sealer/rejuvenator products that have been produced for many years. These are designed to seal and also somewhat rejuvenate pavement surfaces. GSB- 88 is an emulsified seal coat material that requires dilution with an equal amount of water prior to application. GSB-78 is a solvent-based product that seals the pavement surface, and the 
manufacturer indicates that it also provides for some rejuvenation of the pavement.

\section{Field Performance}

The field performance data from numerous airfields were presented to the authors at the start of this evaluation. These data included photographs of pavements coated with the RPS as well as dates of follow-on applications, indicating customer satisfaction with previous work. The rate of application of the RPS material ranged from 0.36 to $0.68 \mathrm{~L} / \mathrm{sq} \mathrm{m}(0.08$ to $0.15 \mathrm{gal} / \mathrm{sq} \mathrm{yd})$, depending on the condition of the existing pavement surface. The rate of application of sand, when required, ranged from 0.25 to $1.1 \mathrm{~kg} / \mathrm{sq} \mathrm{m}(0.5$ to $2.0 \mathrm{lb} / \mathrm{sq} \mathrm{yd})$. The rates of RPS and sand applied are determined based upon the condition of the pavement surface; with greater amounts used for dry or open-textured surfaces. Skid resistance tests over a 3-year period on a road application showed performance basically equal to that of a control section. The field data provided showed that ASI-RPS could be an effective preventive maintenance pavement sealer.

Portland International (PDX) Airport. An ongoing application project of RPS on Runway 10R-28L at PDX was visually evaluated in August 2000. The runway pavement being seal coated with the RPS material had been in place for about 4 years. The grooved hot-mix asphalt (HMA) runway was experiencing raveling of surface aggregate that had recently become increasingly more severe (Photo 1). A few of the most severely raveled areas had been patched with HMA. The areas on the runway that were not patched were sealed with the RPS material (Photo 2).

The application of the diluted RPS material involved the spray application of the emulsion at a rate of $0.9 \mathrm{~L} / \mathrm{sq} \mathrm{m}(0.2 \mathrm{gal} / \mathrm{sq} \mathrm{yd})$. Hand-held squeegees were used to assist in applying the sealer in areas that could not be reached with the spray bar (Photo 3). The application rate had to be monitored or excess RPS material would get into the pavement grooves and flow out through the lower edge of the runway (Photo 4). The concentrated RPS had been delivered to the Portland, OR, area in a rail car. A sand-sized aggregate was immediately applied to the surface after the application of the RPS. The aggregate applied was a 30-60 material, indicating that at least 95 percent of the aggregate passed the $600-\mu \mathrm{m}$ (No. 30) sieve and at least 95 percent of the aggregate was retained on the $250-\mu \mathrm{m}$ (No. 60) sieve. The rate of application ranged from 0.34 to $0.45 \mathrm{~kg} / \mathrm{sq} \mathrm{m}(0.75$ to $1 \mathrm{lb} / \mathrm{sq}$ yd $)$. The aggregate was applied using large dump trucks with spreading units attached to the back (Photo 4).

The contractor was able to get a uniform application of the RPS emulsion and the cover aggregate onto the pavement. Because it was a spray application, the grooves in the pavement surface were not completely filled. Along with the aggregate added, the surface should remain sufficiently skid resistant. Some excess emulsion flowed through the grooves to the edge of the runway because of its slope. This excess emulsion was worked and spread on the shoulder by hand squeegees (Photo 4). 


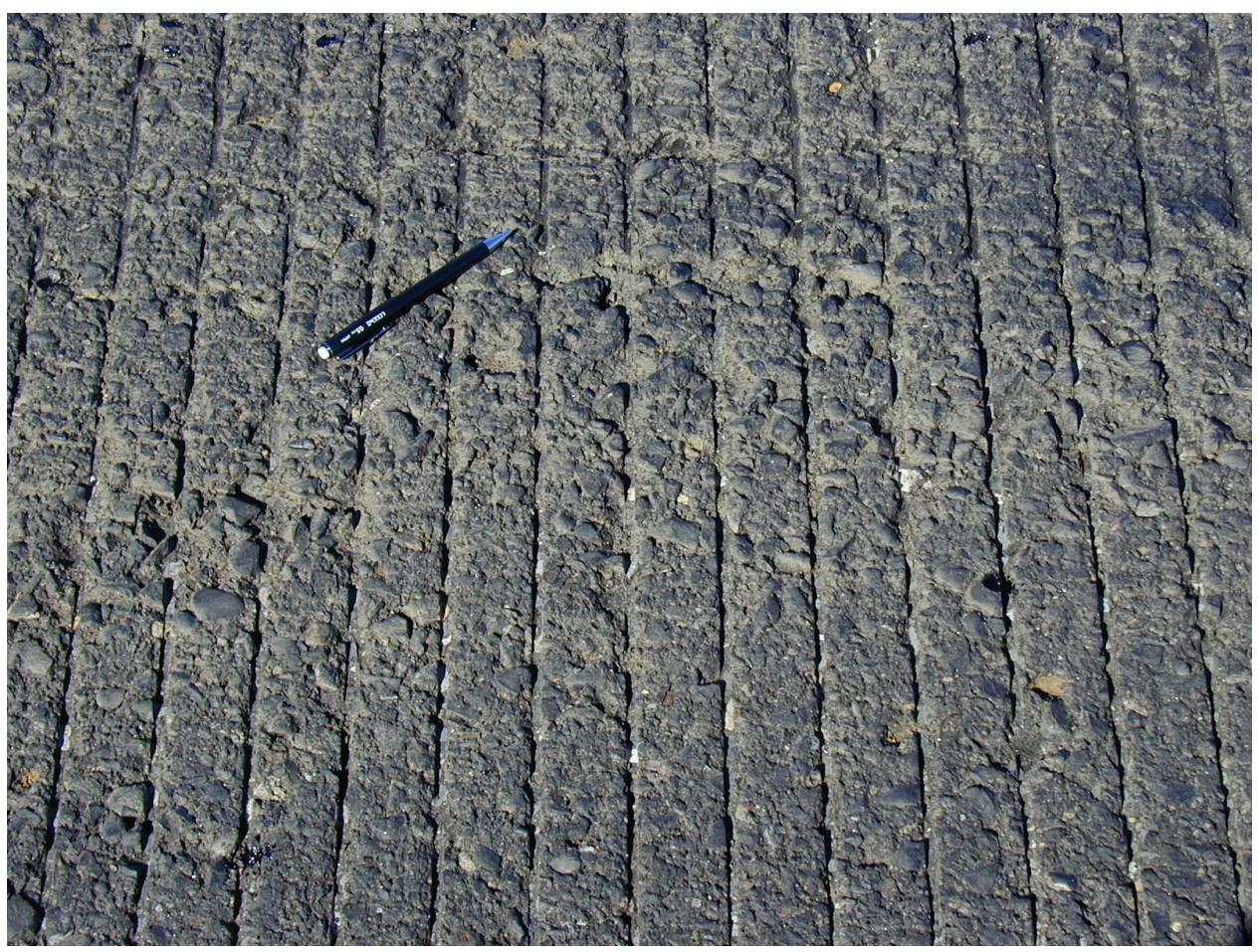

Photo 1. Raveling of grooved hot-mix asphalt pavement on Runway 10R-28L

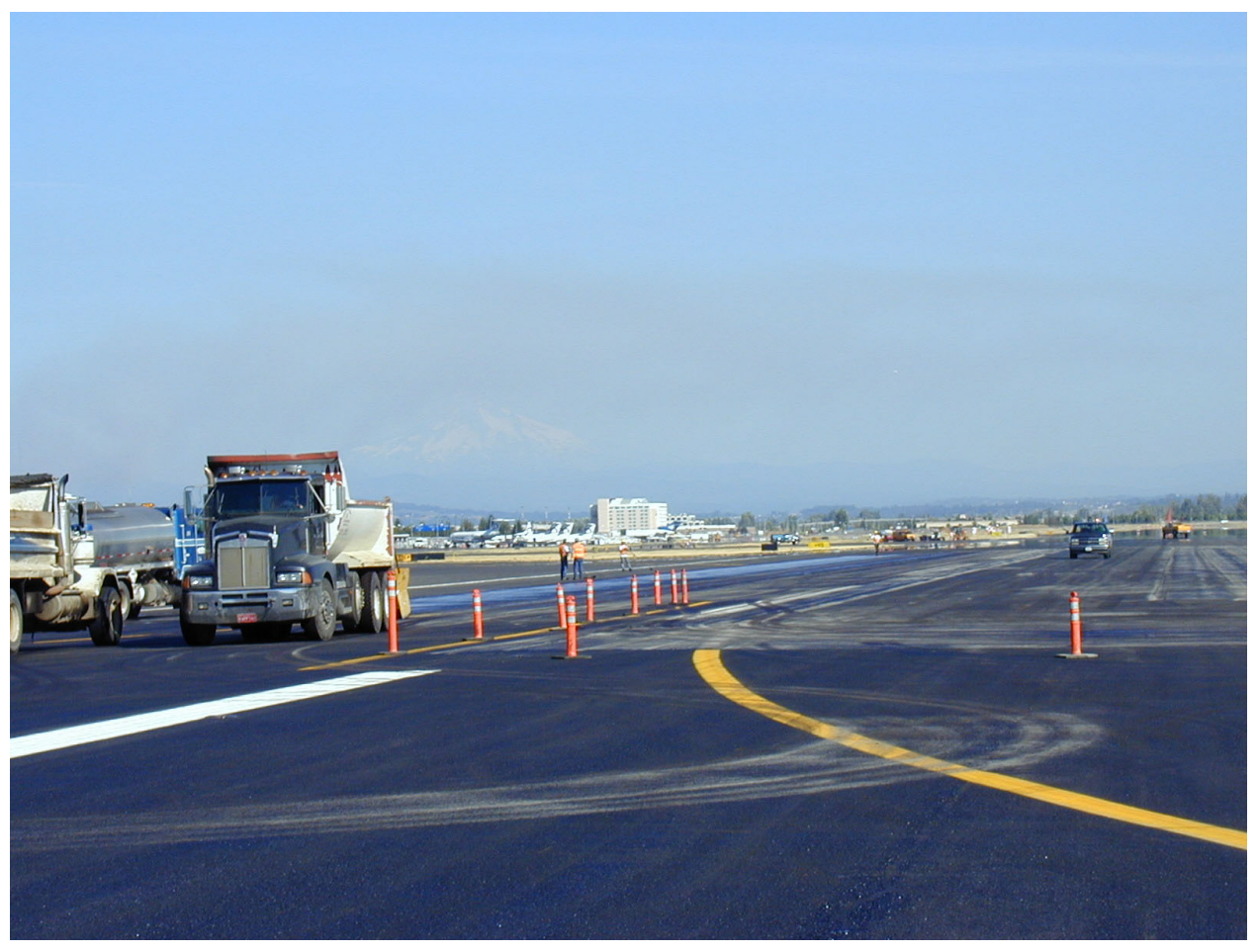

Photo 2. Overall view of Runway 10R-28L, with patched area in foreground 


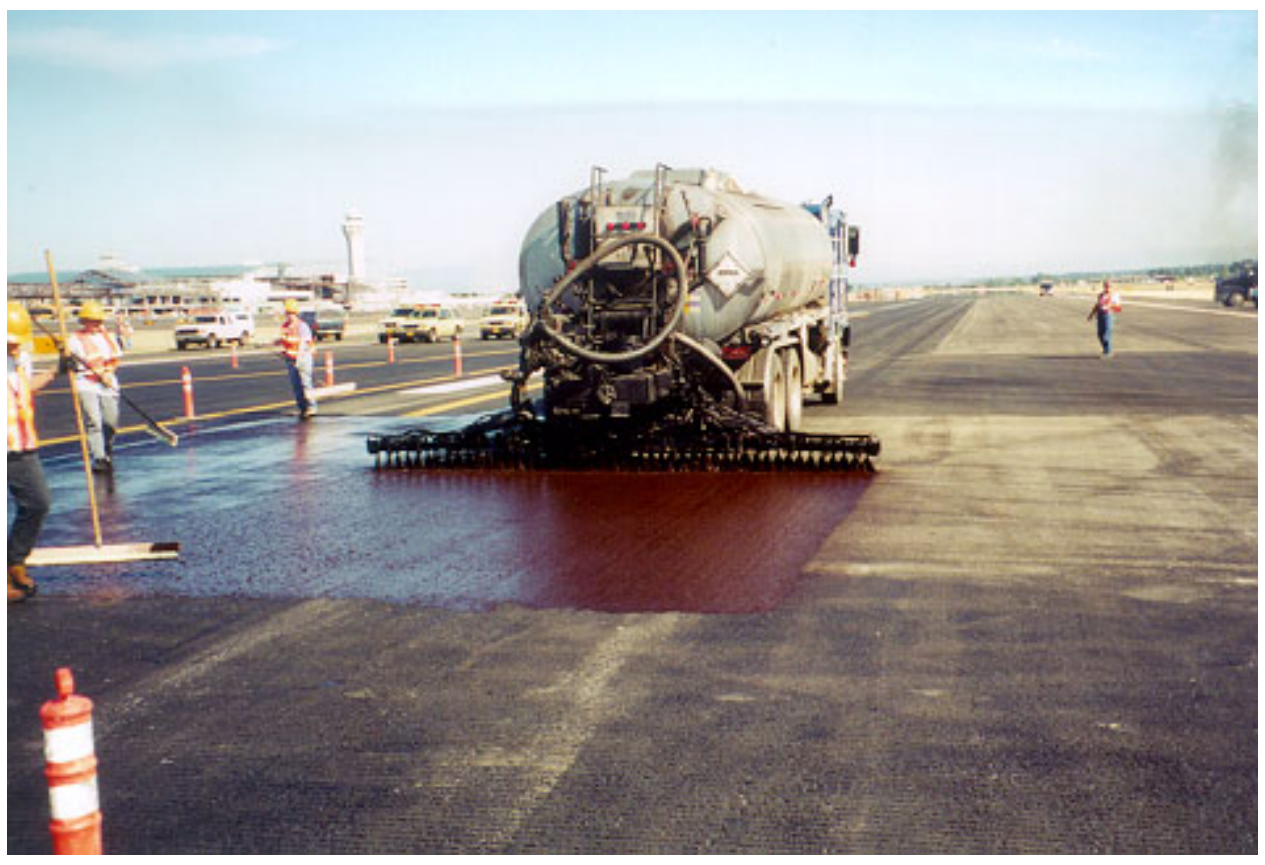

Photo 3. Applying ASI-RPS emulsion to Runway 10R-28L

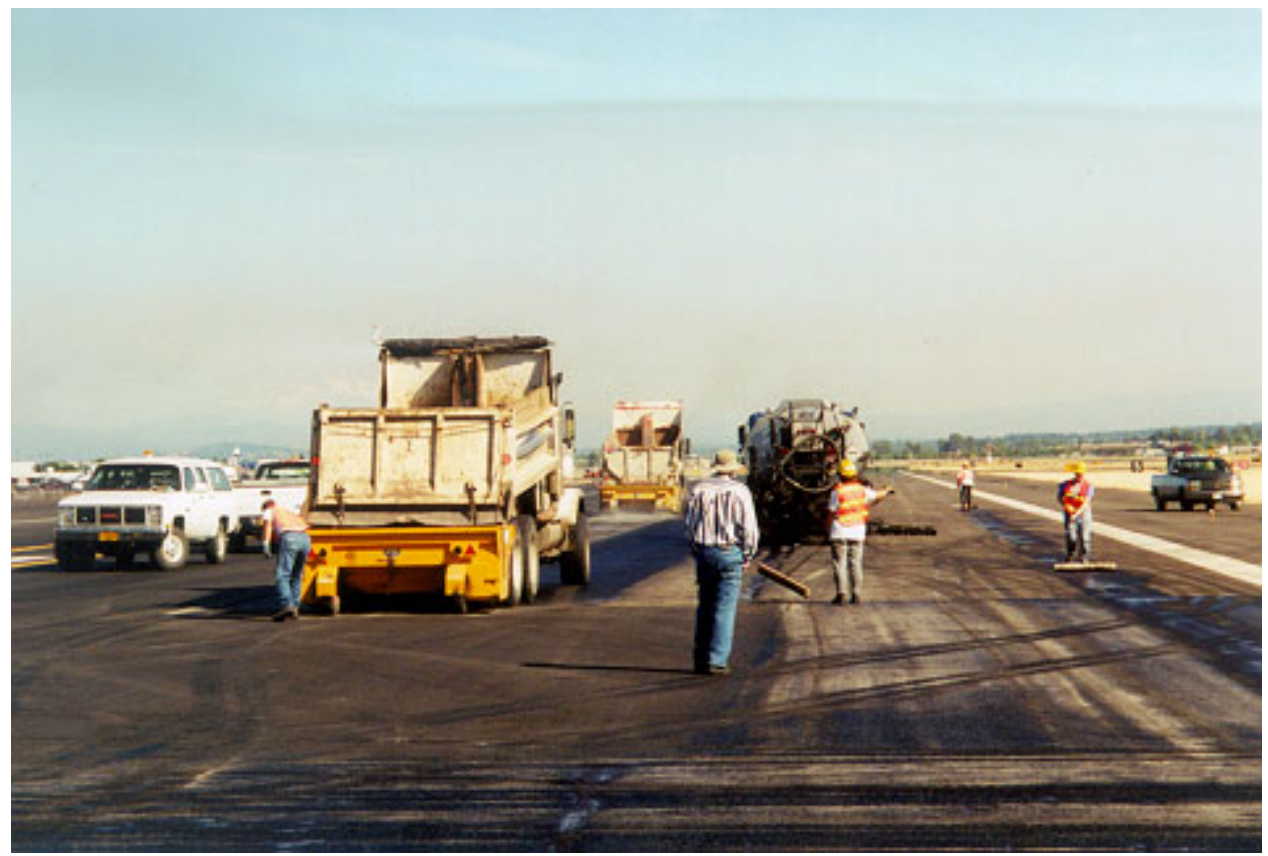

Photo 4. Applying aggregate to the runway. Note the squeegeeing of excess material on the edge of the grooved pavement

While observing the seal coating work on the runway, it was possible to observe a cross taxiway that had been placed in 1997 and then immediately sealed with the manufacturer's GSB- 88 product (Photo 5). According to the manufacturer, application of the GSB- 88 emulsion sealer will penetrate and add 


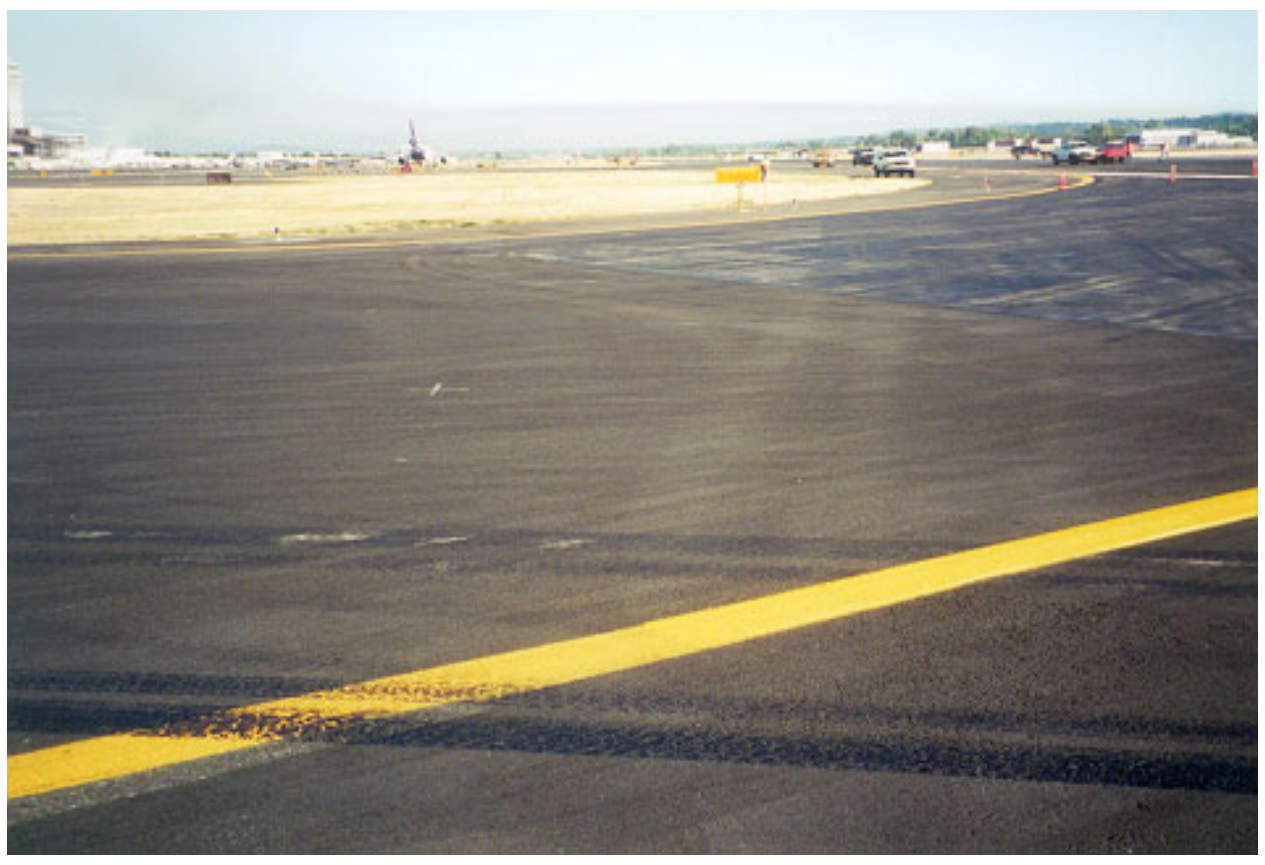

Photo 5. Cross taxiway, previously treated with a sealer product from ASI

new strength to the asphalt binder. GSB- 88 also provides a long lasting antioxidative seal to the pavement surface. The pavement was in excellent condition, being 3 years old, and there were no comparable noncoated areas for comparison.

Mulino General Aviation Airport. The runway of the Mulino General Aviation Airport, near Portland, OR, was visually evaluated on 23 August 2000 (Photo 6). The airport runway had been paved 9 years earlier and then coated with GSB-88 2 years after that. According to the manufacturer, the HMA pavement had been constructed with a very absorptive aggregate. Prior to application of the coating, the pavement surface had become very dry and began to experience some raveling. The pavement was coated with $0.77 \mathrm{~L} / \mathrm{sq} \mathrm{m}$ $(0.17 \mathrm{gal} / \mathrm{sq} \mathrm{yd})$ of GSB- 88 . The sealer is designed to penetrate sufficiently to prevent traffic from wearing it off the surface (Photo 7). Aggregate is not normally required; however, for smooth-surface pavements, it can be applied when required to absorb the excess GSB-88.

The pavement currently is in very good condition with the only noticeable defect being the short longitudinal construction joint crack (Photo 8). The appearance of the pavement surface was relatively consistent throughout the entire pavement surface. 


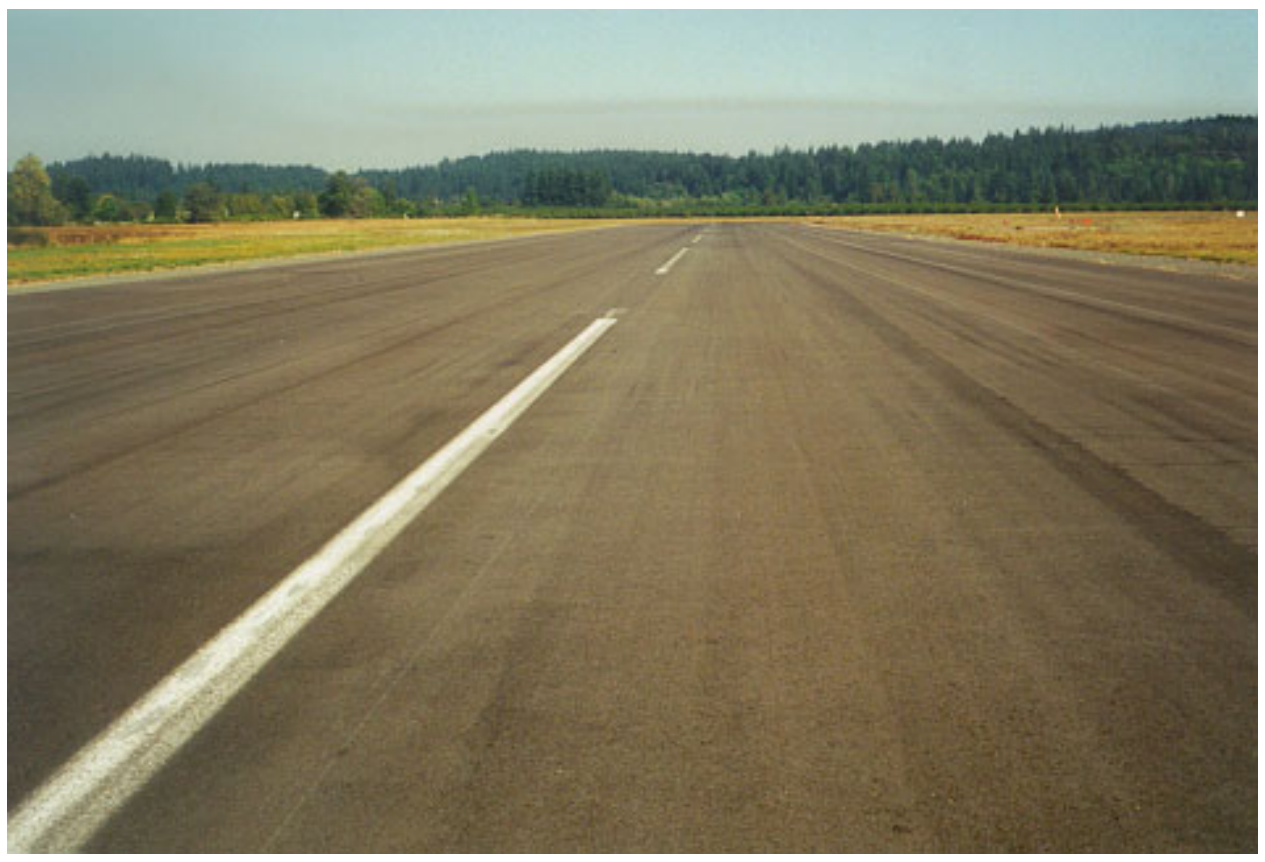

Photo 6. Overall view of Mulino General Aviation Airport

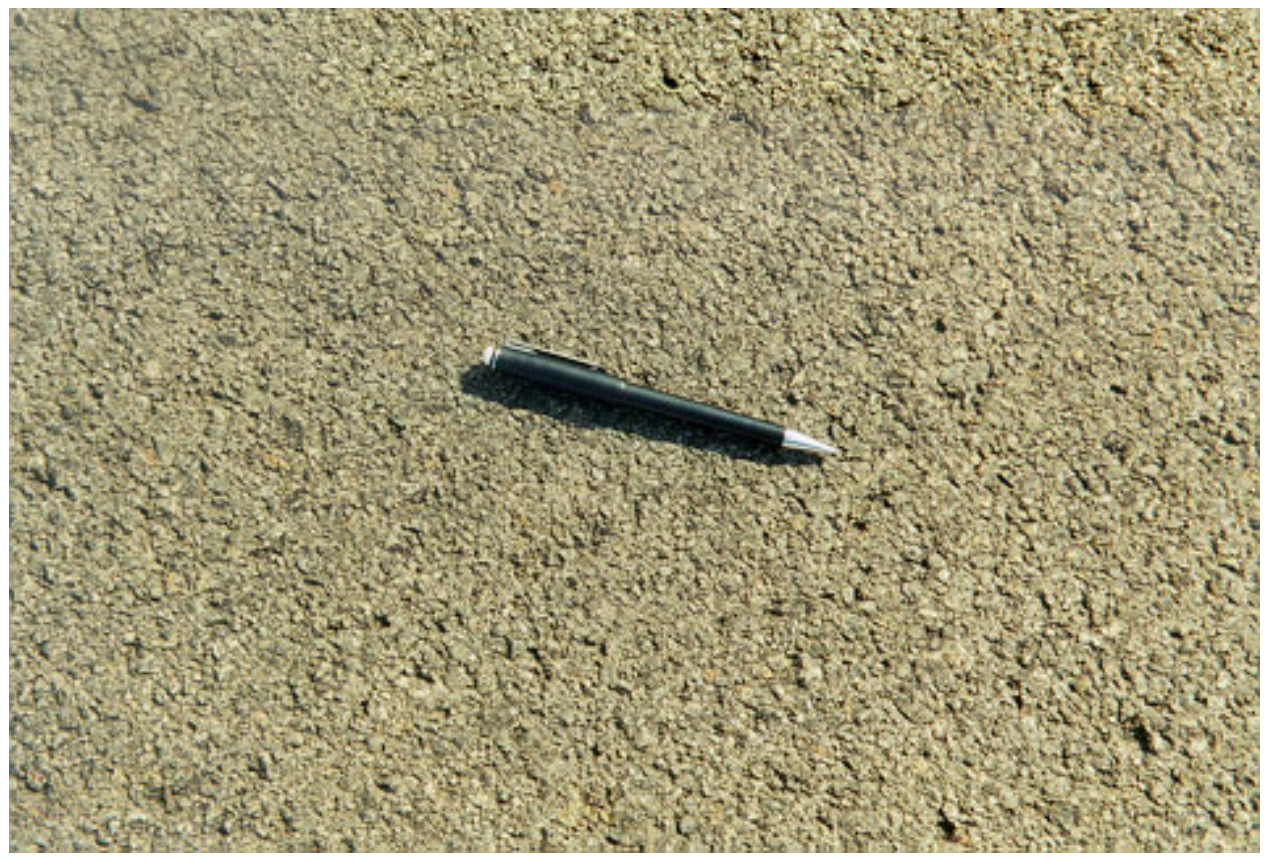

Photo 7. Closeup view of the existing pavement surface at Mulino Airport 


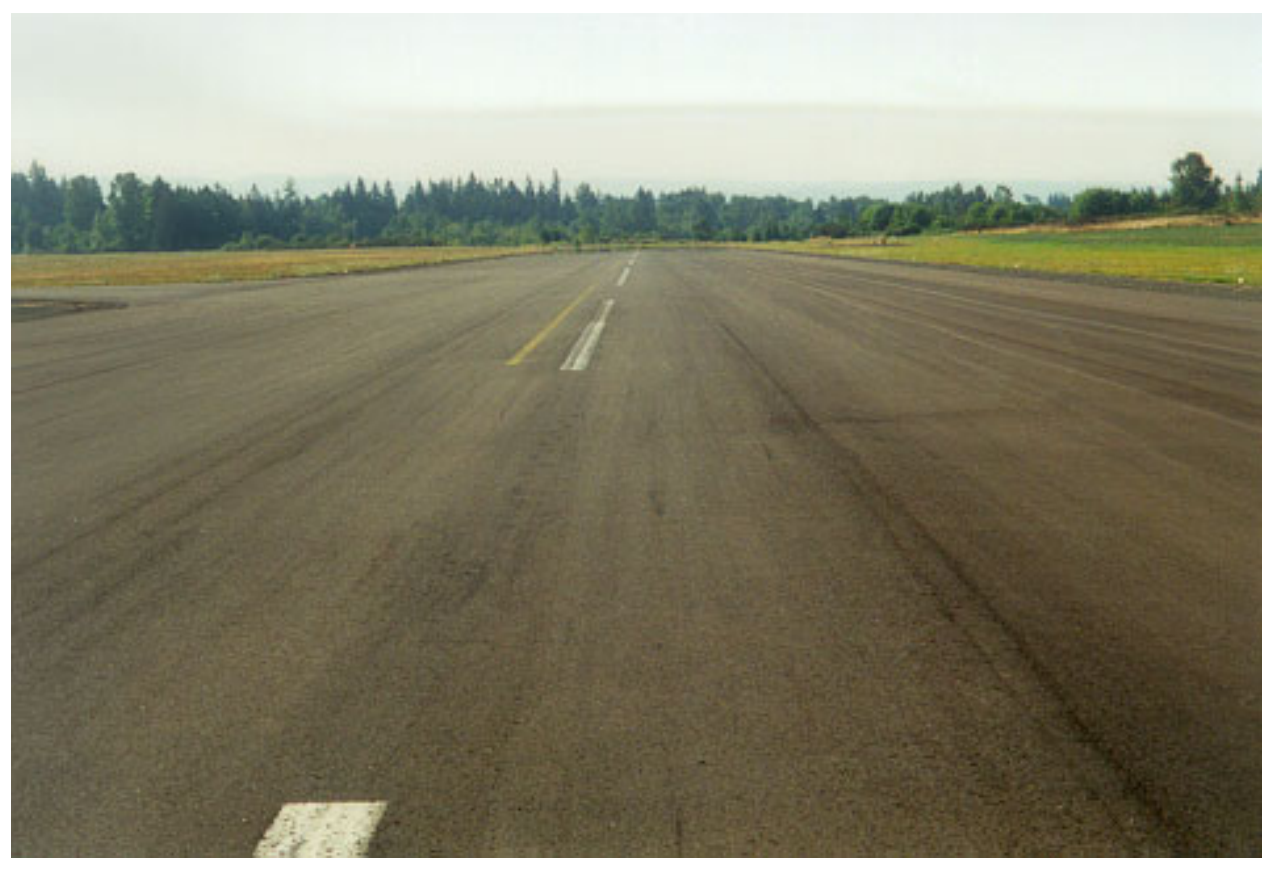

Photo 8. A short crack along the longitudinal construction joint 


\section{Laboratory Evaluation}

\section{General}

The goal of the laboratory study was to evaluate the engineering properties of the RPS material that are related to its effectiveness as a pavement sealer. In general, the program evaluated the properties of the RPS residue and its impact on the existing binder and the ability of the residue to retain aggregate and impact the skid resistance. Test methods and protocols for these types of evaluation do not exist. Instead, available test methods were adopted to yield results that could be used to produce a viable evaluation of the sealer. Several test procedures and methods to determine the material's rheological properties were attempted but not used because of problems encountered in sample preparation or testing. These problems centered on developing procedures that evaluated the material as a sealer or coating.

\section{Rheological Properties}

Materials. Table 1 lists the penetration and viscosity values for the RPS material and a cationic slow cure (CSS-1) emulsion that was used as a comparison material. The CSS-1 was obtained from a local asphalt supplier and was thought to be typical of what might be used in the area as a seal coat or fog seal application. The RPS emulsion is also a cationic emulsion.

\begin{tabular}{|c|c|c|}
\hline \multicolumn{3}{|c|}{$\begin{array}{l}\text { Table1 } \\
\text { Penetration and Viscosity of ASI-RPS and CSS-1 Emulsions }\end{array}$} \\
\hline Material & Penetration $^{1}, 0.1 \mathrm{~mm}$ & Viscosity $^{2}$, centistokes \\
\hline ASI-RPS & $\overline{177}$ & (5,994 \\
\hline CSS-1 & 103 & 418 \\
\hline \multicolumn{3}{|c|}{$\begin{array}{l}\text { American Society for Testing Materials (ASTM). (2000a). ASTM D 5, "Standard test method for } \\
\text { penetration of bituminous materials," D 5, Vol 4.03, West Conshohocken, PA. } \\
\text { 2ASTM. (2000b). ASTM D 2170, "Standard test method for kinematic viscosity of asphalts } \\
\text { (bituminous)," West Conshohocken, PA. }\end{array}$} \\
\hline
\end{tabular}


The dynamic shear rheometer (DSR) was used to evaluate the material properties of both binders according to the American Society of State Highway and Transportation Officials (AASHTO) TP5. ${ }^{1}$ The DSR test values for the phase angle $(\delta)$ and the shear modulus $\left(\mathrm{G}^{*}\right)$ were obtained for each binder material at $60{ }^{\circ} \mathrm{C}\left(140^{\circ} \mathrm{F}\right)$. Table 2 lists the results obtained from the DSR evaluation.

\begin{tabular}{|c|c|c|}
\hline Material & Phase Angle ( $\delta$, degrees) & 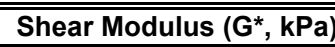 \\
\hline ASI-RPS & 62.08 & 58.00 \\
\hline CSS-1 & 82.50 & 3.12 \\
\hline
\end{tabular}

Sealed Specimens. A laboratory test program was conducted to evaluate the effectiveness of RPS material at protecting an asphalt surface from aging. The laboratory testing method selected for this evaluation involved the coating of a number of Marshall test samples with various test materials. It was assumed that the relatively thin coatings that were placed on the specimens would not have a substantial effect on the Marshall test results. The Marshall test specimens were fabricated using crushed limestone and AC-30 (PG 64-22) asphalt. The aggregate met the standard U.S. Army Corps of Engineers (USACE) airfield mixture gradation and was blended with 4.7 percent asphalt cement, Table 3 . The mixture was compacted with 75 blows of a Marshall mechanical hammer.

\begin{tabular}{|c|c|}
\hline \multicolumn{2}{|c|}{$\begin{array}{l}\text { Table } 3 \\
\text { Aggregate Gradation for Marshall Specimens }\end{array}$} \\
\hline Sieve Size, mm (in.) & \% Passing \\
\hline $19 \mathrm{~mm}(3 / 4 \mathrm{in})$ & 100 \\
\hline $12.5 \mathrm{~mm}(1 / 2 \mathrm{in})$ & \begin{tabular}{|l|}
99 \\
\end{tabular} \\
\hline $9.5 \mathrm{~mm}(3 / 8 \mathrm{in})$ & 88 \\
\hline $4.75 \mathrm{~mm}$ (No. 4 ) & 68 \\
\hline $2.36 \mathrm{~mm}$ (No. 8) & 53 \\
\hline $1.18 \mathrm{~mm}$ (No. 16$)$ & 40 \\
\hline $600 \mu \mathrm{m}$ (No. 30) & 30 \\
\hline $300 \mu \mathrm{m}$ (No. 50) & 21 \\
\hline $150 \mu \mathrm{m}$ (No. 100$)$ & 14 \\
\hline $75 \mu \mathrm{m}$ (No. 200) & 6 \\
\hline
\end{tabular}

To evaluate the effectiveness of RPS as a seal coat, the material with light and heavy coatings of RPS was compared against uncoated control specimens, Table 4. Other materials used to seal or coat Marshall specimens included CSS-1 emulsion, coal tar emulsion, and saran plastic wrap. The two emulsions are typical of what is normally applied for seal coating of asphalt pavements to provide a barrier to oxygen. The Saran wrap was used to try to provide an airtight seal (oxygen barrier) around the specimen. The values provided for these materials are only for reference and are not intended for comparative purposes.

${ }^{1}$ American Association of State Highway and Transportation Officials. (2000).
"Standard test method for determining the rheological properties of asphalt binder using a
dynamic shear rheometer (DSR), provincial standards," AASHTO TP5, Washington, DC. 
Prior to coating, the compacted Marshall specimens were each weighed to obtain an uncoated weight and then weighed again after the application of the material, Table 4. This allowed for an estimation of the amount of material applied to each specimen. The various seal coat materials were applied with a paintbrush, in a uniform application, over the entire surface of each specimen. The specimens were allowed to cure under laboratory conditions for at least $48 \mathrm{hr}$ prior to the start of the oven curing.

The plain and coated specimens were aged by curing the specimens in a forced-draft oven at $60{ }^{\circ} \mathrm{C}\left(140^{\circ} \mathrm{F}\right)$ for 1 to 60 days, as given in Table 4 . These cure times were arbitrarily selected to provide a reasonable time frame for testing and to provide a reasonable change in the amount of aging of the specimens. Oven aging of a specimen will normally result in the hardening of the asphalt binder and an increase in the Marshall stability and flow values. A comparison of the Marshall properties obtained was intended as a method of evaluating the effectiveness of the seal coat.

\begin{tabular}{|c|c|c|c|c|c|c|c|}
\hline \multicolumn{8}{|c|}{$\begin{array}{l}\text { Table } 4 \\
\text { Results of Marshall Mixture Tests on Cured and Uncured Specimens }\end{array}$} \\
\hline \begin{tabular}{|l|} 
Sample \\
No. \\
\end{tabular} & Material & \begin{tabular}{|l|} 
Days \\
Cured
\end{tabular} & $\begin{array}{l}\text { Wt before } \\
\text { Coating, g }\end{array}$ & $\begin{array}{l}\text { Wt after } \\
\text { Coating, } \mathbf{g}\end{array}$ & Difference & $\begin{array}{l}\begin{array}{l}\text { Stability } \\
\text { Ib/force }\end{array} \\
\end{array}$ & $\begin{array}{l}\text { Flow } \\
0.25 \mathrm{~mm}\end{array}$ \\
\hline 1 & Uncoated & 1 & $1,253.1$ & $1,252.2$ & -0.9 & $2,800.0$ & 13.0 \\
\hline 2 & Uncoated & 1 & $1,255.2$ & $1,255.7$ & 0.5 & $3,600.0$ & 12.0 \\
\hline 3 & Uncoated & 1 & $1,257.1$ & $1,257.7$ & 0.6 & $3,350.0$ & 14.0 \\
\hline 4 & Uncoated & 60 & $1,257.1$ & $1,258.0$ & 0.9 & $4,310.0$ & 15.5 \\
\hline 5 & Uncoated & 60 & $1,252.2$ & $1,252.8$ & 0.6 & $4,525.0$ & 15.0 \\
\hline 6 & Uncoated & 60 & $1,261.5$ & $1,261.6$ & 0.1 & $4,350.0$ & 15.5 \\
\hline 7 & Saran Wrap & 60 & $1,249.8$ & $1,250.1$ & 0.3 & $4,250.0$ & 15.0 \\
\hline 8 & Saran Wrap & 60 & $1,256.7$ & $1,256.8$ & 0.1 & $3,960.0$ & 14.5 \\
\hline 9 & Saran Wrap & 60 & $1,250.6$ & $1,250.9$ & 0.3 & $4,200.0$ & 15.5 \\
\hline 10 & Emulsion & 1 & $1,256.1$ & $1,260.2$ & 4.1 & $2,550.0$ & 14.0 \\
\hline 11 & Emulsion & 1 & $1,245.9$ & $1,249.2$ & 3.3 & $2,750.0$ & 14.0 \\
\hline 12 & Emulsion & 1 & $1,253.8$ & $1,257.2$ & 3.4 & $2,750.0$ & 14.0 \\
\hline 13 & Emulsion & 60 & $1,249.9$ & $1,253.2$ & 3.3 & $4,625.0$ & 15.5 \\
\hline 14 & Emulsion & 60 & $1,253.9$ & $1,257.1$ & 3.2 & $4,000.0$ & 15.5 \\
\hline 15 & Emulsion & 60 & $1,254.9$ & $1,257.9$ & 3.0 & $3,550.0$ & 15.0 \\
\hline 16 & Coal Tar & 1 & $1,244.6$ & $1,249.1$ & 4.5 & $2,950.0$ & 16.0 \\
\hline \begin{tabular}{|l}
17 \\
\end{tabular} & Coal Tar & 1 & $1,255.9$ & $1,260.0$ & 4.1 & $3,100.0$ & 14.0 \\
\hline 18 & Coal Tar & 1 & $1,251.4$ & $1,255.5$ & 4.1 & $3,000.0$ & 14.0 \\
\hline 19 & Coal Tar & 60 & $1,254.1$ & $1,257.8$ & 3.7 & $3,860.0$ & 14.0 \\
\hline 20 & Coal Tar & 60 & $1,253.7$ & $1,257.4$ & 3.7 & $3,880.0$ & 15.0 \\
\hline \begin{tabular}{|l|}
21 \\
\end{tabular} & Coal Tar & 60 & $1,260.3$ & $1,264.1$ & 3.8 & $3,775.0$ & 16.0 \\
\hline 22 & Light RPS & 1 & $1,255.9$ & $1,260.5$ & 4.6 & $2,625.0$ & 13.0 \\
\hline \begin{tabular}{|l|}
23 \\
\end{tabular} & Light RPS & 1 & $1,254.1$ & $1,259.0$ & 4.9 & $2,900.0$ & 15.0 \\
\hline 24 & Light RPS & 1 & $1,254.7$ & $1,260.4$ & 5.7 & $2,625.0$ & 15.0 \\
\hline 25 & Light RPS & 60 & $1,256.3$ & $1,262.2$ & 5.9 & $3,925.0$ & 17.0 \\
\hline 26 & Light RPS & 60 & $1,257.9$ & $1,263.3$ & 5.4 & $4,100.0$ & 17.0 \\
\hline \begin{tabular}{|l|}
27 \\
\end{tabular} & Light RPS & 60 & $1,256.1$ & $1,262.1$ & 6.0 & $3,775.0$ & 17.0 \\
\hline \begin{tabular}{|l|}
28 \\
\end{tabular} & Heavy RPS & 1 & $1,247.1$ & $1,258.7$ & 11.6 & $2,100.0$ & 14.0 \\
\hline 29 & Heavy RPS & 1 & $1,253.3$ & $1,263.6$ & 10.3 & $2,100.0$ & 15.0 \\
\hline 30 & Heavy RPS & 1 & $1,251.8$ & $1,263.9$ & 12.1 & $2,200.0$ & 14.0 \\
\hline 31 & Heavy RPS & 60 & $1,255.2$ & $1,266.9$ & 11.7 & $3,072.0$ & 18.0 \\
\hline 32 & Heavy RPS & 60 & $1,249.9$ & $1,261.4$ & 11.5 & $3,275.0$ & 22.0 \\
\hline 33 & Heavy RPS & 60 & $1,249.9$ & $1,260.7$ & 10.8 & $3,325.0$ & 19.0 \\
\hline
\end{tabular}


After this initial curing period, the coated specimens were then weighed to determine the relative amount of material applied to the specimens, Table 4 . The Marshall test was then performed on each specimen and the stability and flow values were recorded.

\section{Durability}

Durability testing was conducted by comparing the RPS emulsion to a standard cationic CSS-1 emulsion with an abrasion test. Specimens of each emulsion were abraded using a scrub tester as described in ASTM D 2486, ${ }^{1}$ modified to use a wire brush and surcharge weight (Photo 9). The abrasion test was intended to demonstrate the ability of the two types of emulsion to hold sand-size aggregate in place on a pavement surface. The scrub tests were run on sample specimens both before and after oven aging (to simulate field aging).

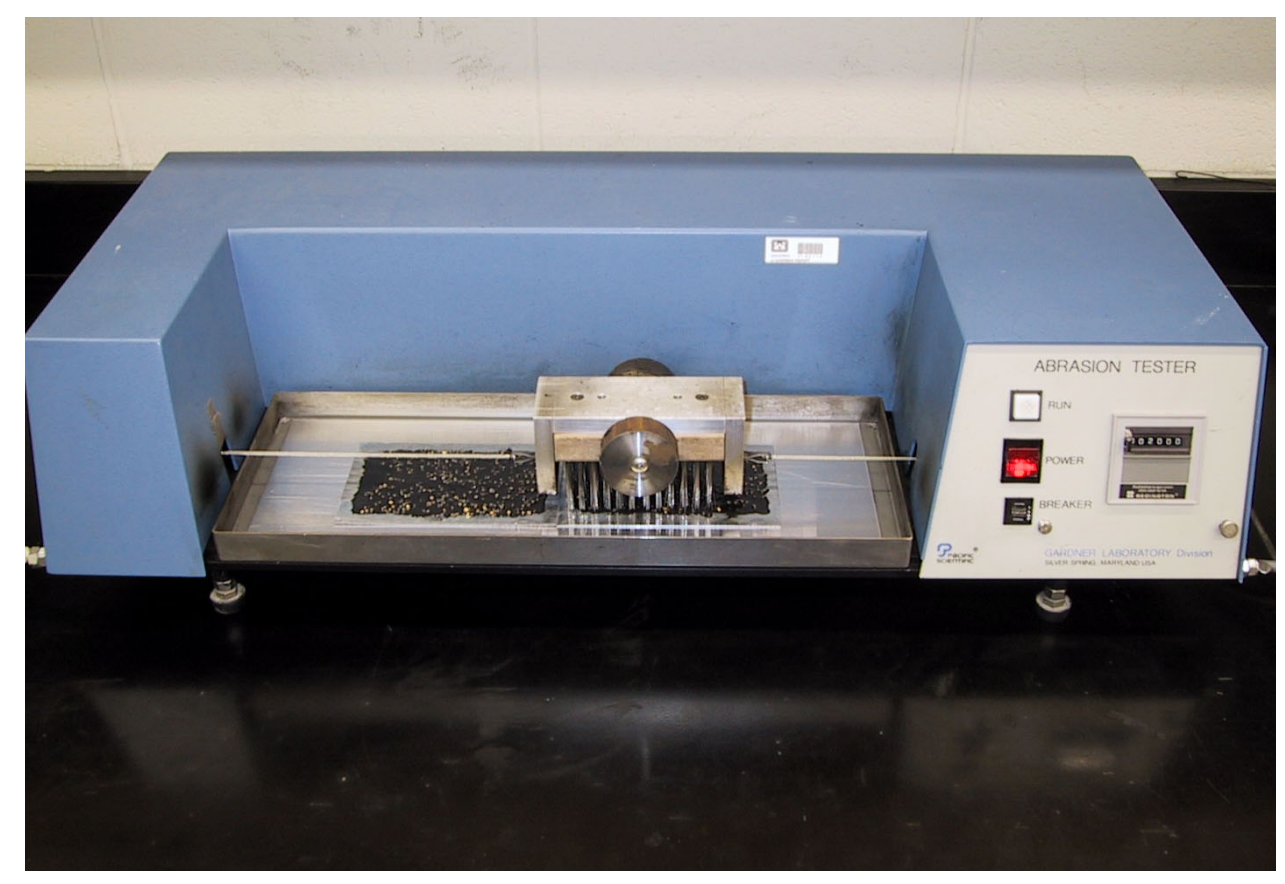

Photo 9. Scrub tester, with wire brush and weights. Note: two specimens beneath brush

The binder materials were applied with a paintbrush to a galvanized steel plate. Silica sand that passed the No. 16 sieve and was retained on the No. 30 sieve was applied to the uncured binder. The sand was applied with a fabricated device (similar to a salt shaker) to apply an approximately even distribution of sand over the specimen surface. The specimens were cured for $24 \mathrm{hr}$ prior to the oven curing. All specimens were cured in a forced-draft oven for the times shown in Table 5.

${ }^{1}$ ASTM. (2000). "Standard test methods for scrub resistance of wall paints," D 2486, Vol 6.02, West Conshohocken, PA. 


\begin{tabular}{|c|c|c|c|c|c|}
\hline \multicolumn{6}{|c|}{$\begin{array}{l}\text { Table } 5 \\
\text { Results of Scrub Testing with 1,000 Cycles }\end{array}$} \\
\hline \multirow[b]{2}{*}{ Specimen } & \multicolumn{2}{|c|}{ Hours of Oven ${ }^{1}$ Curing } & \multirow[b]{2}{*}{ Initial $\mathbf{W t}^{2}, \mathbf{g}$} & \multirow[b]{2}{*}{$\mathbf{W t}^{2}$ after Scrub, $\mathbf{g}$} & \multirow[b]{2}{*}{$\%$ Loss } \\
\hline & $60^{\circ} \mathrm{C}$ & $120^{\circ} \mathrm{C}$ & & & \\
\hline CSS-1: 1 & 24 & --- & 5.9682 & 5.1986 & 12.90 \\
\hline CSS-1: 2 & 24 & --- & 5.6655 & 4.873 & 13.99 \\
\hline CSS-1: 3 & 24 & --- & 6.0208 & 5.1649 & 14.22 \\
\hline CSS-1: 4 & 144 & --- & 7.8464 & 7.4702 & 4.79 \\
\hline CSS-1: 5 & 144 & --- & 6.0948 & 5.3723 & 11.85 \\
\hline CSS-1: 6 & --- & 120 & 6.9099 & 6.8738 & 0.52 \\
\hline CSS-1: 7 & --- & 120 & 6.2516 & 6.1952 & 0.90 \\
\hline CSS-1: 8 & --- & 120 & 5.2962 & 5.2666 & 0.56 \\
\hline RPS: 1 & 24 & --- & 9.1663 & 9.0909 & 0.82 \\
\hline RPS: 2 & 24 & --- & 6.379 & 6.3097 & 1.09 \\
\hline RPS: 3 & 24 & --- & 7.3422 & 7.2572 & 1.16 \\
\hline RPS: 4 & 144 & --- & 8.8964 & 8.8079 & 0.99 \\
\hline RPS: 5 & 144 & --- & 7.6905 & 7.5884 & 1.33 \\
\hline RPS: 6 & --- & 120 & 8.6243 & 8.4607 & 1.90 \\
\hline RPS: 7 & --- & 120 & 10.4824 & 10.3269 & 1.48 \\
\hline RPS: 8 & --- & 120 & 8.6545 & 8.506 & 1.72 \\
\hline
\end{tabular}

The abrasion device used was a stainless steel wire brush. The total weight of the scrub head, with the brush holder and other weights, was $601.3 \mathrm{~g}$ for specimens CSS-1: 1, CSS-1:2, RPS: 1, and RPS: 2. For the remaining specimens the weight was increased to $1,205.2 \mathrm{~g}$. Two specimens at a time were evaluated in the scrub-testing device. The specimens were abraded for 1,000 cycles in the device. The abrasion was conducted with just enough water added to the specimen tray to keep them slightly underwater.

A second set of specimens containing an increased amount of aggregate placed on them during fabrication was also tested (Photo 10). Table 6 lists the results of this second set of scrub testing. The aging regimen and the initial test procedure was the same as before, except that after testing specimens C1-1, C2-1, A1-1, and A2-1, a cable broke in the scrub-testing device and further testing was delayed 2 weeks until a new part was obtained. The remaining specimens were then tested at 1,000 cycles and the percent weight loss determined. An additional 2,000 cycles were then given to each specimen and the weight loss again determined. 


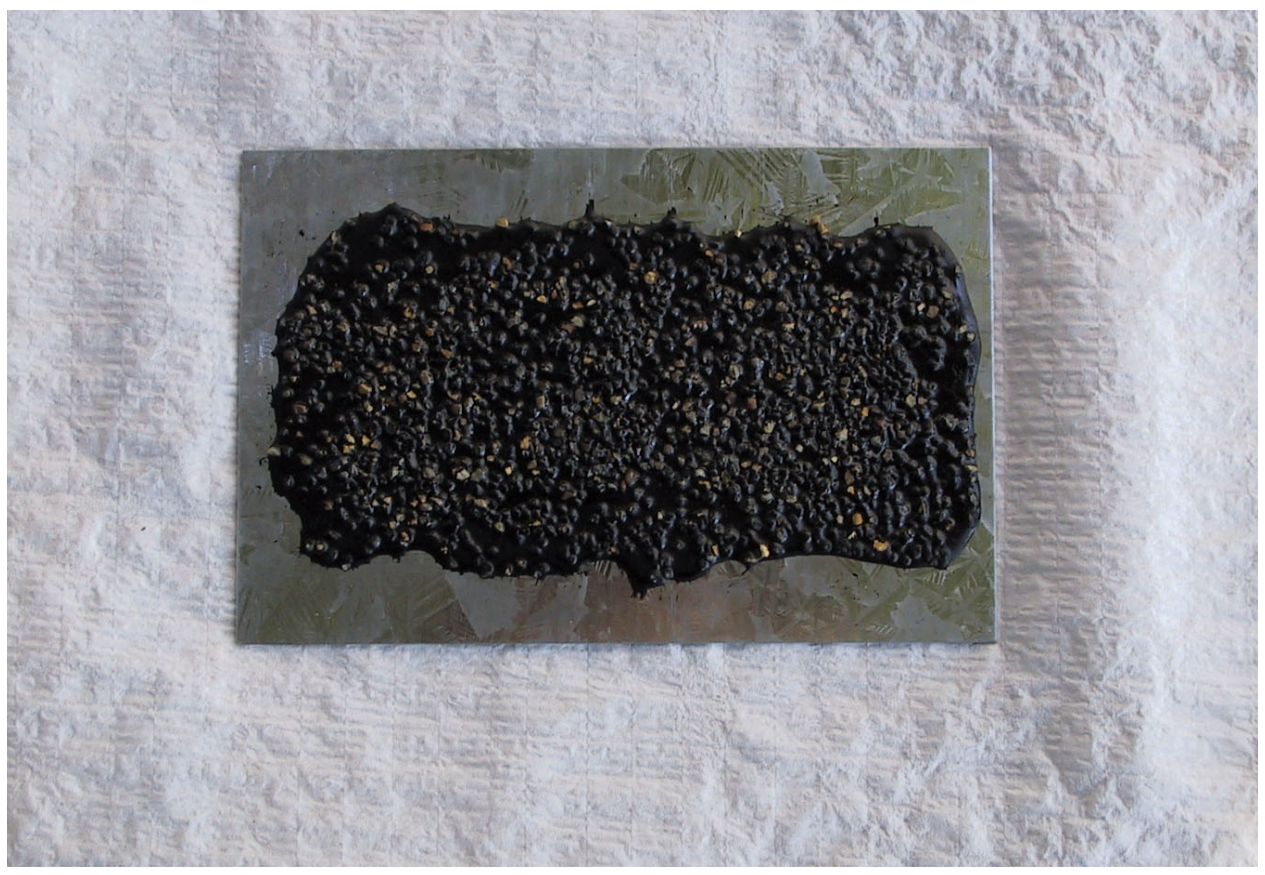

Photo 10. Test specimen containing ASI-RPS emulsion, prior to abrasion testing

\section{Results}

Rheological results. The results of the penetration, viscosity, and DSR tests (given in Tables 1 and 2) showed that the residual binder material in the RPS emulsion was considerably harder than the residual binder material in the CSS-1 emulsion. The three test methods all indicated this type of behavior.

The stability and flow results on the sealed specimens are given in Table 7. These results include the mean and coefficient of variation (COV) of the three individual Marshall tests of each material and curing condition. The COV values obtained for the coated specimens were generally within the range of those obtained for the uncoated specimens. This was also true for the range of COV values obtained for the different curing times. These data show that compared to all types of coatings, the uncoated specimens had the highest mean stability values. This indicates that all of the coatings used were at least somewhat effective in protecting or reducing the amount of aging that occurred within the asphalt core. The relatively low stability value obtained with the heavy application of the RPS may indicate that some material penetrated and softened the asphalt binder of these cores. 


\begin{tabular}{|c|c|c|c|c|c|c|c|}
\hline $\begin{array}{l}\text { Table } 6 \\
\text { Results } \\
1,000 \text { an }\end{array}$ & $\begin{array}{l}\text { Scrub } \\
3,000\end{array}$ & $\begin{array}{l}\text { stins } \\
\text { les }\end{array}$ & ith Large & nount & f Agg & ate & \\
\hline & $\mathrm{Hr}$ of Ov & Curing & & $\overline{W^{2}{ }^{2} \text { after }}$ & crub, $\mathrm{g}$ & \% L & \\
\hline Specimen & $60^{\circ} \mathrm{C}$ & $120^{\circ} \mathrm{C}$ & Initial $\mathbf{W} \mathbf{t}^{2}, \mathbf{g}$ & 1,000 & 3,000 & 1,000 & 3,000 \\
\hline CSS-1: 1-1 & 24 & --- & 10.488 & 9.456 & 9.451 & 9.84 & 9.89 \\
\hline CSS-1: 2-1 & 24 & --- & 12.080 & 10.853 & 10.847 & 10.16 & 10.21 \\
\hline CSS-1: 3-1 & 24 & --- & 12.508 & 11.935 & 11.619 & 4.58 & 7.11 \\
\hline CSS-1: 4-1 & 144 & --- & 16.080 & 15.809 & 15.629 & 1.69 & 2.81 \\
\hline CSS-1: 5-1 & 144 & --- & 15.102 & 14.832 & 14.516 & 1.79 & 3.88 \\
\hline CSS-1: 6-1 & 144 & --- & 11.975 & 11.740 & 11.210 & 1.96 & 6.38 \\
\hline CSS-1: 7-1 & --- & 120 & 11.524 & 11.482 & 11.443 & 0.36 & 0.70 \\
\hline CSS-1: 8-1 & --- & 120 & 12.577 & 12.526 & 12.491 & 0.41 & 0.69 \\
\hline CSS-1: 9-1 & --- & 120 & 10.897 & 10.840 & 10.813 & 0.53 & 0.78 \\
\hline RPS: $1-1$ & 24 & --- & 8.493 & 8.264 & 8.259 & 2.69 & 2.75 \\
\hline RPS: 2-1 & 24 & --- & 12.296 & 11.931 & 11.922 & 2.97 & 3.04 \\
\hline RPS: $3-1$ & 24 & --- & 12.566 & 12.369 & 12.248 & 1.57 & 2.54 \\
\hline RPS: 4-1 & 144 & --- & 14.901 & 14.772 & 14.647 & 0.86 & 1.70 \\
\hline RPS: $5-1$ & 144 & --- & 12.070 & 11.916 & 11.800 & 1.27 & 2.23 \\
\hline RPS: $6-1$ & 144 & --- & 16.688 & 16.496 & 16.385 & 1.15 & 1.81 \\
\hline RPS: $7-1$ & --- & 120 & 16.491 & 16.406 & 16.250 & 0.52 & 1.46 \\
\hline RPS: 8-1 & --- & 120 & 13.426 & 13.313 & 13.116 & 0.84 & 2.31 \\
\hline RPS: $9-1$ & --- & 120 & 13.764 & 13.655 & 13.467 & 0.79 & 2.16 \\
\hline
\end{tabular}

The Marshall test results were evaluated through a statistical analysis conducted using SPSS software, windows version 10.0. This analysis used the results from each individual test with a one-way analysis of variance (ANOVA). As part of this analysis, a multiple comparison procedure (homogeneity of variance analysis option) was conducted using the Tukey HSD multiple-range test, with a 95-percent confidence level. The comparisons are reported using the letters ' $A$ ', ' $B$ ', 'A/B', etc. The letter ' $A$ ' is used to rank a coating material with the lowest Marshall value, with the remaining letters indicating a significant increase in the Marshall value. A double letter designation, such as 'A/B', indicates that the Marshall values of a particular coating were not significantly different from either of groups ' $A$ ' or ' $B$ '.

The results of the comparison analysis are given graphically in Figures 1 and 2. These figures show that regardless of the curing procedure used, the uncoated specimens developed the highest Marshall values, indicating these specimens experienced the most aging or hardening. These figures also show that the specimens coated with a heavy application of the RPS material had the lowest Marshall values, regardless of the amount of curing. The statistical differences obtained after 60 days were expected; however, it was surprising that a difference occurred after just 1 day of curing. This result would suggest that there had been some penetration and softening of the original asphalt binder of these cores.

The weight difference, as given in Table 4, shows that the amount of a particular material added to each core was relatively consistent. An actual rate of 


\begin{tabular}{|c|c|c|c|c|c|c|}
\hline $\begin{array}{l}\text { Table } \\
\text { Mean }\end{array}$ & cov of & shal & ire Tes & sult & & \\
\hline Sample & & Days & & bility & & \\
\hline No. & Material & Cured & Mean & cov & Mean & cov \\
\hline 1 & Uncoated & 1 & $2,800.0$ & & 13.0 & \\
\hline 2 & Uncoated & 1 & $3,600.0$ & & 12.0 & \\
\hline 3 & Uncoated & 1 & $3,350.0$ & & 14.0 & \\
\hline & & & $3,250.0$ & 12.59 & 13.0 & 7.69 \\
\hline 4 & Uncoated & 60 & $4,310.0$ & & 15.5 & \\
\hline 5 & Uncoated & 60 & $4,525.0$ & & 15.0 & \\
\hline 6 & Uncoated & 60 & $4,350.0$ & & 15.5 & \\
\hline & & & $4,395.0$ & 2.6 & 15.3 & 1.88 \\
\hline 7 & Saran Wrap & 60 & $4,250.0$ & & 15.0 & \\
\hline 8 & Saran Wrap & 60 & $3,960.0$ & & 14.5 & \\
\hline 9 & Saran Wrap & 60 & $4,200.0$ & & 15.5 & \\
\hline & & & $4,137.0$ & 3.75 & 15.0 & 3.33 \\
\hline 10 & Emulsion & 1 & $2,550.0$ & & 14.0 & \\
\hline 11 & Emulsion & 1 & $2,750.0$ & & 14.0 & \\
\hline 12 & Emulsion & 1 & $2,750.0$ & & 14.0 & \\
\hline & & & $2,683.0$ & 4.3 & 14.0 & 0 \\
\hline 13 & Emulsion & 60 & $4,625.0$ & & 15.5 & \\
\hline 14 & Emulsion & 60 & $4,000.0$ & & 15.5 & \\
\hline 15 & Emulsion & 60 & $3,550.0$ & & 15.0 & \\
\hline & & & $4,058.0$ & 13.3 & 15.3 & 1.88 \\
\hline 16 & Coal Tar & 1 & $2,950.0$ & & 16.0 & \\
\hline 17 & Coal Tar & 1 & $3,100.0$ & & 14.0 & \\
\hline 18 & Coal Tar & 1 & $3,000.0$ & & 14.0 & \\
\hline & & & $3,017.0$ & 2.53 & 14.7 & 7.87 \\
\hline 19 & Coal Tar & 60 & $3,860.0$ & & 14.0 & \\
\hline 20 & Coal Tar & 60 & $3,880.0$ & & 15.0 & \\
\hline 21 & Coal Tar & 60 & $3,775.0$ & & 16.0 & \\
\hline & & & $3,838.0$ & 1.45 & 15.0 & 6.67 \\
\hline 22 & Light RPS & 1 & $2,625.0$ & & 13.0 & \\
\hline 23 & Light RPS & 1 & $2,900.0$ & & 15.0 & \\
\hline 24 & Light RPS & 1 & $2,625.0$ & & 15.0 & \\
\hline & & & $2,717.0$ & 5.84 & 14.3 & 8.06 \\
\hline 25 & Light RPS & 60 & $3,925.0$ & & 17.0 & \\
\hline 26 & Light RPS & 60 & $4,100.0$ & & 17.0 & \\
\hline 27 & Light RPS & 60 & $3,775.0$ & & 17.0 & \\
\hline & & & $3,933.0$ & 4.14 & 17.0 & 0 \\
\hline 28 & Heavy RPS & 1 & $2,100.0$ & & 14.0 & \\
\hline 29 & Heavy RPS & 1 & $2,100.0$ & & 15.0 & \\
\hline 30 & Heavy RPS & 1 & $2,200.0$ & & 14.0 & \\
\hline & & & $2,133.0$ & 2.71 & 14.3 & 4.03 \\
\hline 31 & Heavy RPS & 60 & $3,072.0$ & & 18.0 & \\
\hline 32 & Heavy RPS & 60 & $3,275.0$ & & 22.0 & \\
\hline 33 & Heavy RPS & 60 & $3,325.0$ & & 19.0 & \\
\hline & & & $3,224.0$ & 4.16 & 19.7 & 10.59 \\
\hline
\end{tabular}




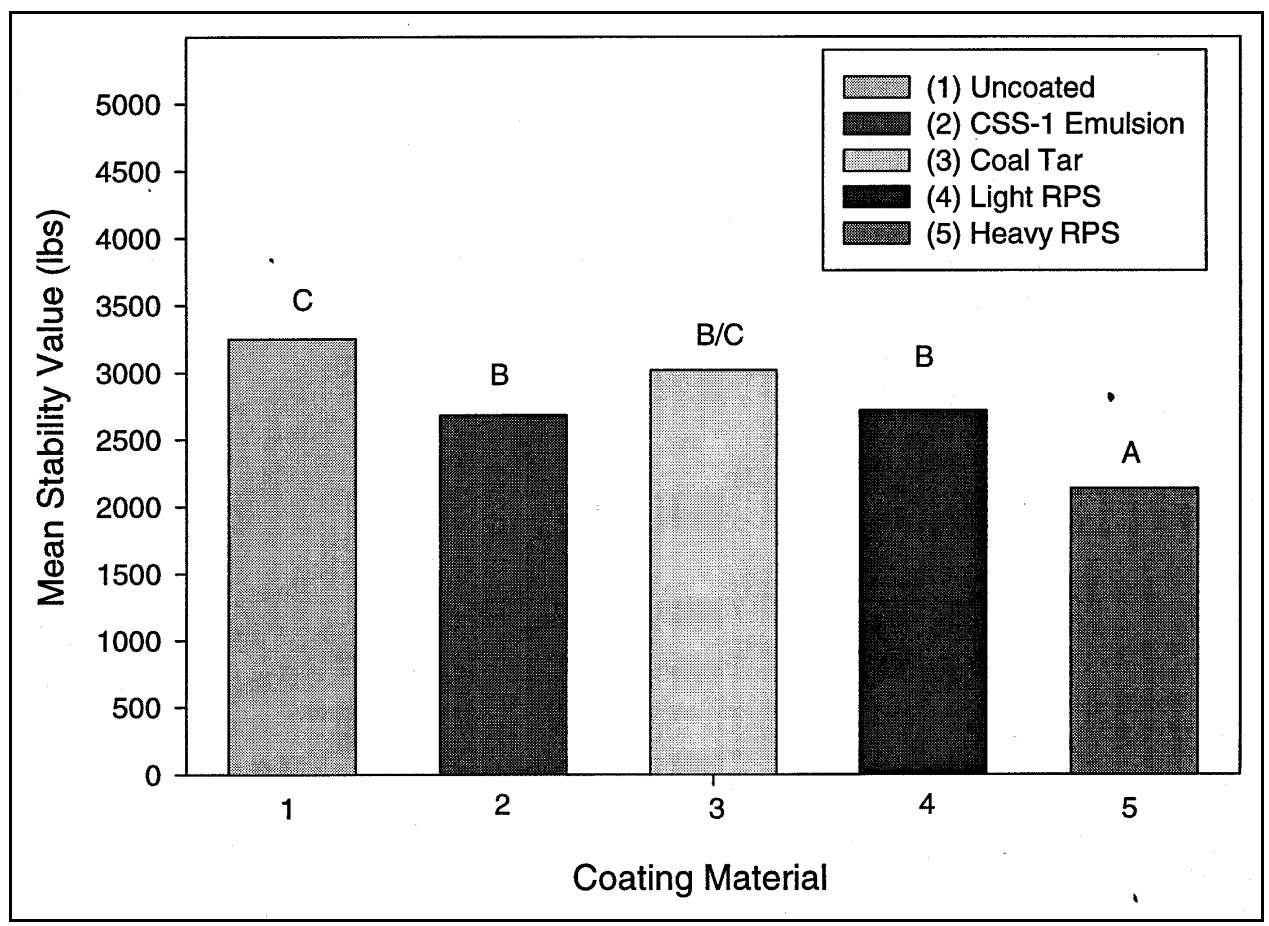

Figure 1. Effect of various coatings on Marshall Stability, with a 1-hr oven cure

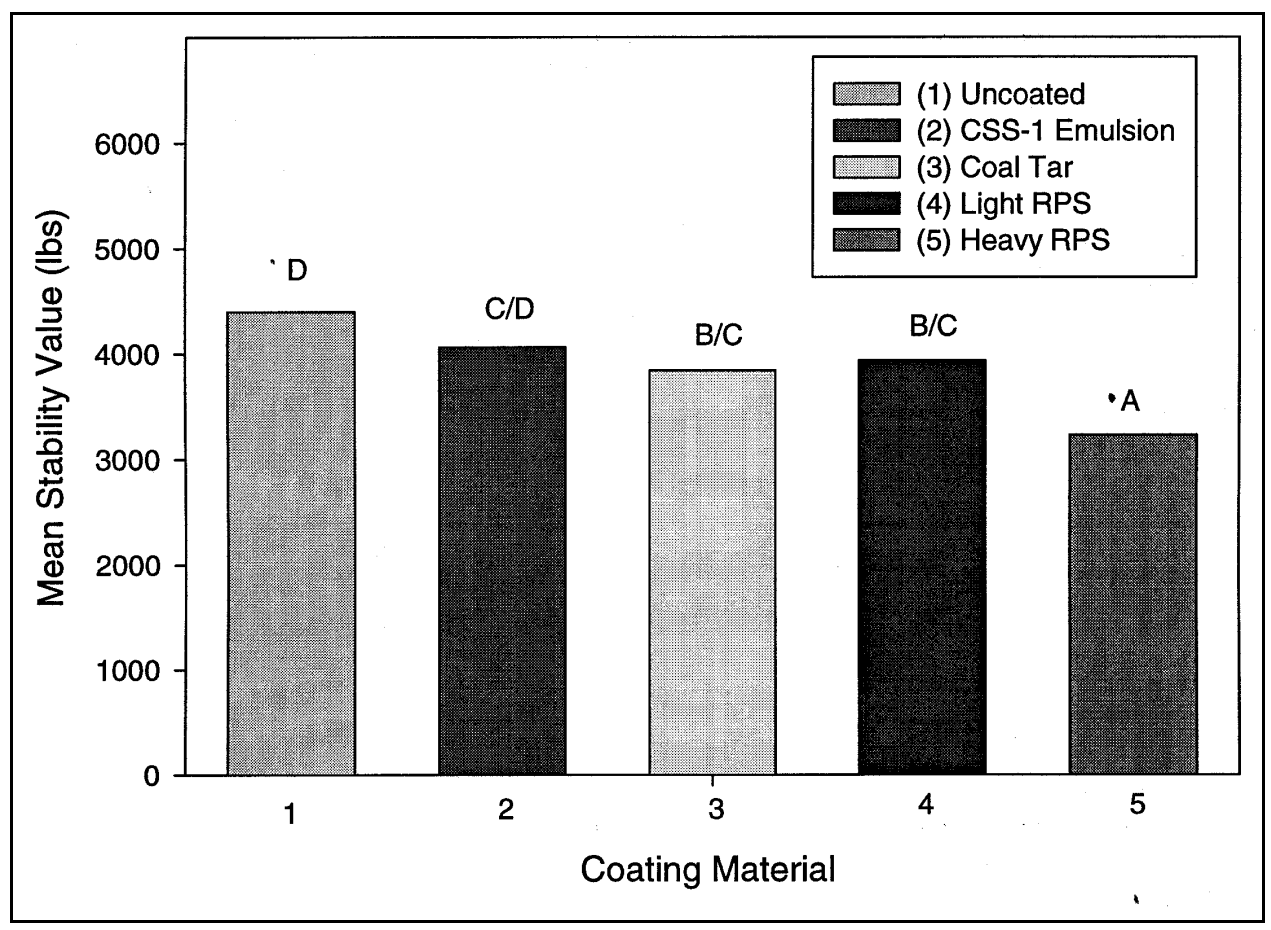

Figure 2. Effect of various coatings on Marshall Stability, with a 60-hr oven cure 
application was not determined, because variations in specific gravity and solids content of the coatings would not provide a valid basis for comparison. Several thickness measurements were taken on the after tested cores and a thickness of 10 mils was obtained for the emulsion coated specimens, while 15 mils was obtained from the specimens with a heavy coating of RPS material. Generally, it would appear that most of the coating materials were probably placed at a thickness of about 10 mils, with the heavy coating of RPS material about 1.5 times that thickness.

Durability. The performance the CSS-1 emulsion and the RPS emulsion binders in holding aggregate applied to the durability (scrub testing) test specimens as previously described is given in Tables 5 and 6 . The CSS-1 emulsion lost aggregate and had a significant weight loss that decreased with increased aging of the residual binder of the emulsion. At high amounts of aging, the CSS-1 emulsion lost only a minimal amount of aggregate. With or without aging, the RPS binder did not lose significant amounts of aggregate. As evidenced by residual binder left on the brush head and water pan, most specimens did have a minor amount of binder removed by abrasion.

A statistical analysis of the test data obtained was conducted using the same SPSS software as used previously. This analysis used an independent-samples t-test for a comparison of means of the test results listed in Tables 5 and 6 . The analysis was split into two parts because these data in Table 5 were based on specimens containing less aggregate than the data in Table 6. Each analysis was split into three parts based on the three different curing procedures that were used. As before, this analysis used the results from each individual test with a one-way ANOVA. As part of this analysis, a multiple comparison procedure (homogeneity of variance analysis option) was conducted using the Tukey HSD multiple-range test, with a 95-percent confidence level. As previously used with the Marshall test results, the letter ' $A$ ' is used to rank a mixture according to the lowest aggregate loss and the remaining letters indicating a significant increase in aggregate loss. The double letter designation, such as 'A/B', indicates that the aggregate loss from a particular binder or curing procedure was not significantly different from either of groups 'A' or 'B'.

The results of the statistical analysis are given in Figures 3, 4, and 5. The results from the two different sets of specimens (Tables 5 and 6) were not directly comparable because of some material volume differences in construction; however, they can provide indications of relative performance. The results for the asphalt emulsion control specimens of all specimen types show a consistent trend whereby specimens lose less aggregate as they are aged. The results for the RPS material varied with the lower amount of aggregate specimens showing a general decrease in the amount of aggregate loss with increased amounts of curing (Figure 3). However, the RPS specimens with increased amounts of aggregate did not show a significant change in the amount of aggregate loss with increased amounts of curing at either the 1,000 or the 3,000 cycles of abrasion (Figures 4 and 5). In most instances, at the highest level of aging (curing), the asphalt emulsion specimens lost significantly less aggregate than comparatively aged RPS specimens. 


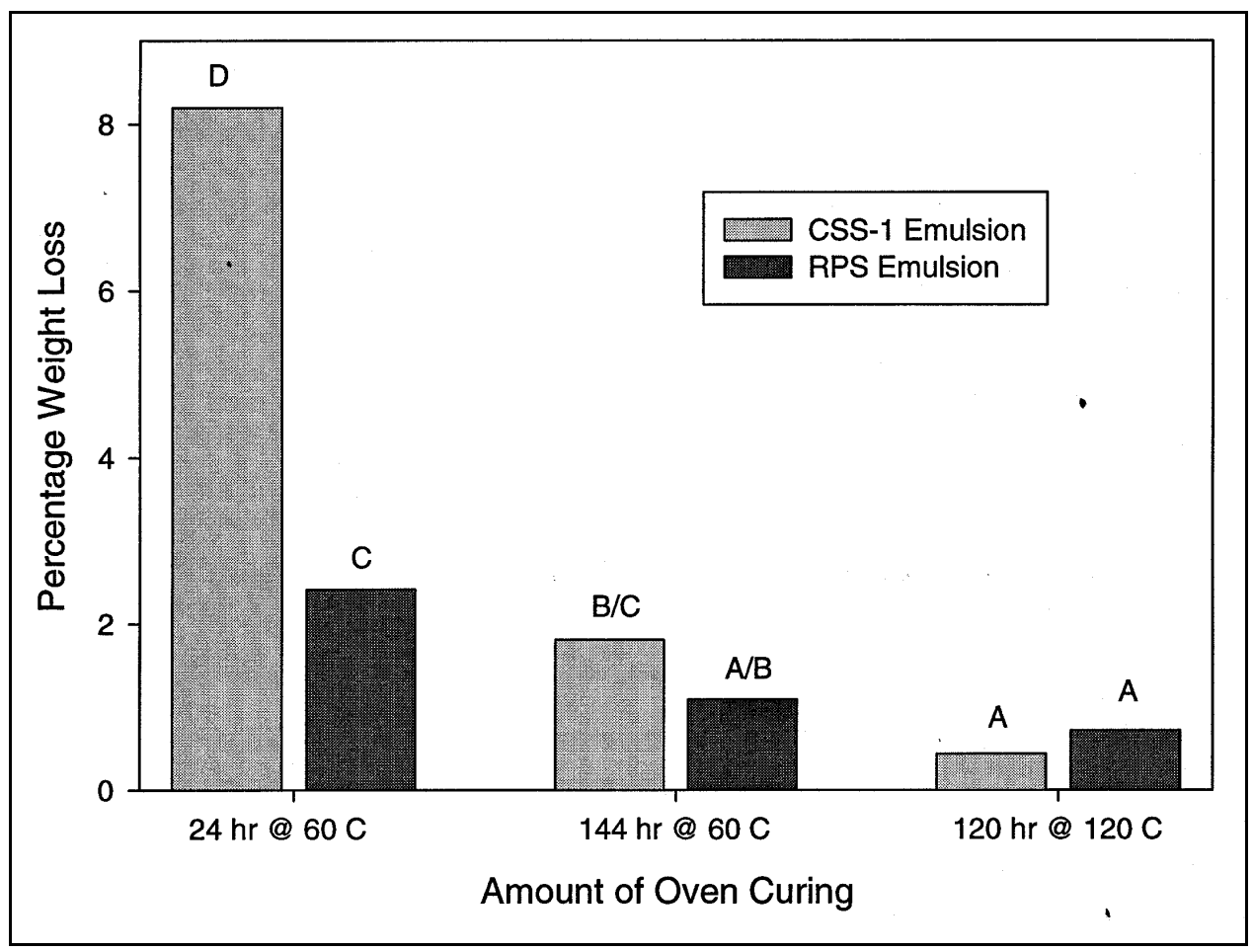

Figure 3. Effect of curing on mass loss after 1,000 scrub cycles

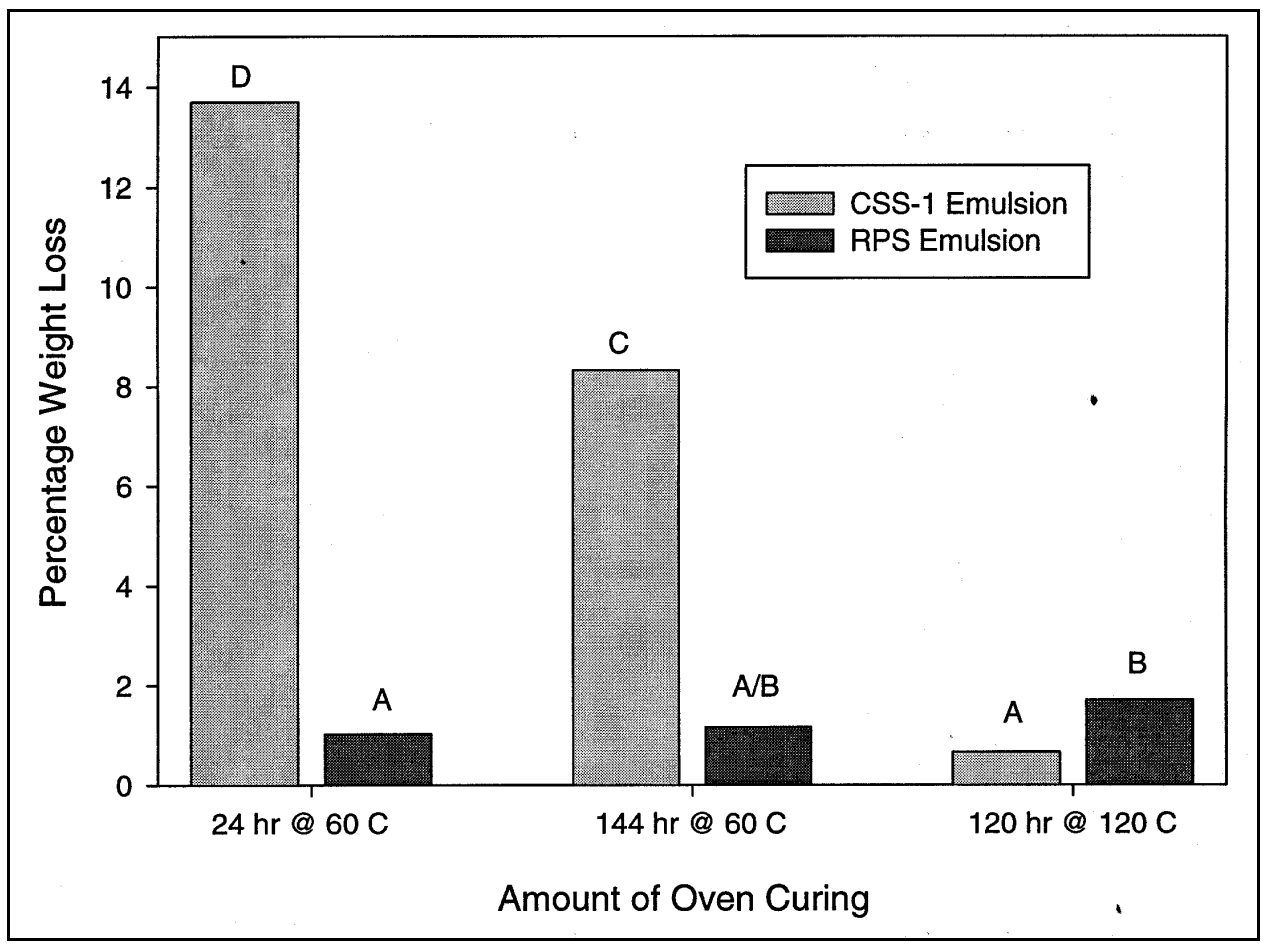

Figure 4. Effect of curing on mass loss (increased aggregate) after 1,000 scrub cycles 


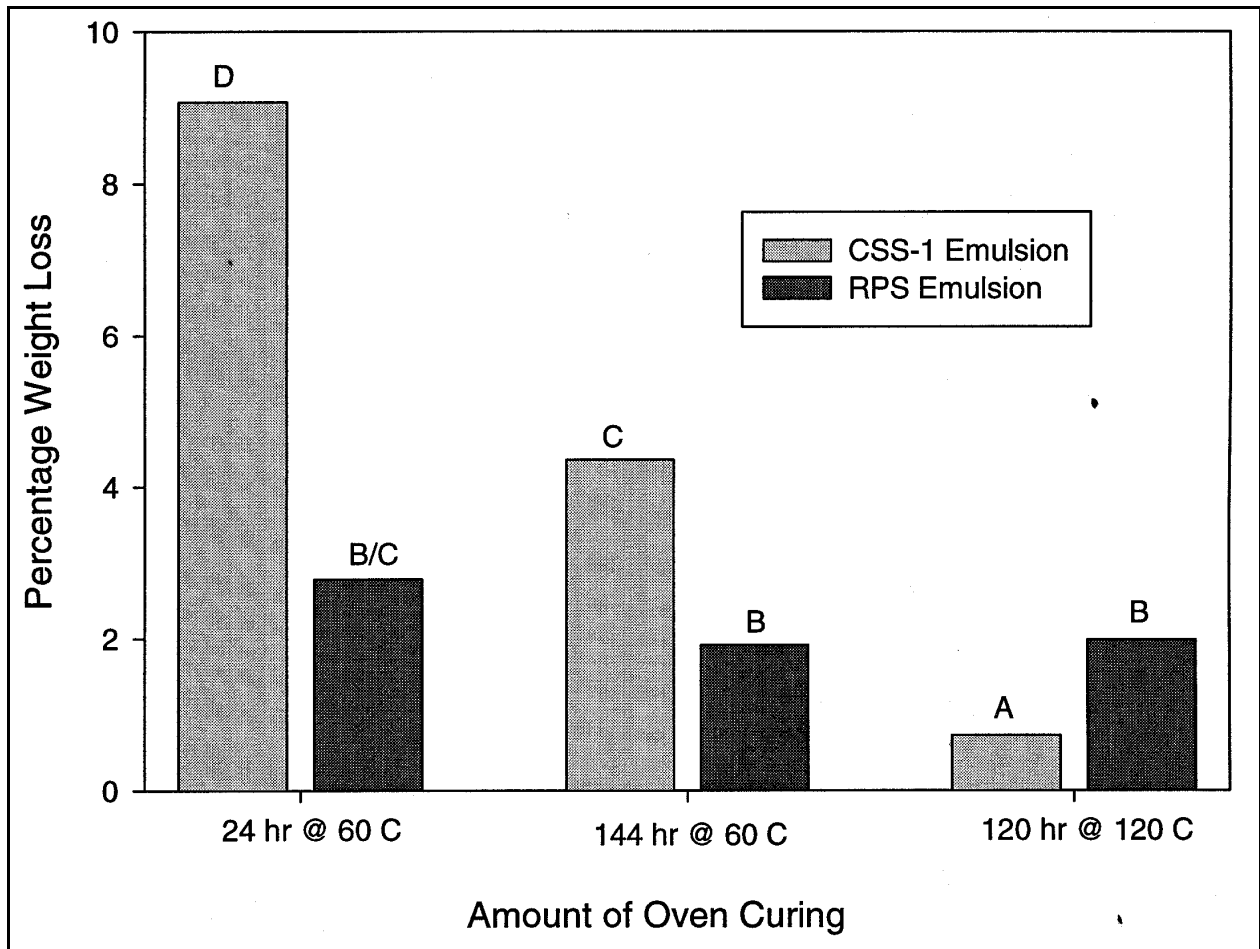

Figure 5. Effect of curing on mass loss (increased aggregate) after 3,000 scrub cycles 


\section{Conclusions and Recommendations}

The following conclusions and recommendations are based on the field and laboratory investigations conducted as part of this study.

\section{Conclusions}

The RPS has been used on a large number of general aviation airfields since 1990, and it has been used on a few commercial airfields since 1992. Sand is added during application to provide adequate high-speed skid resistance. The lack of comparative control sections hinders a complete evaluation of the materials effectiveness.

Evaluation of the Marshall test results indicated that the application of a seal coat material could protect an asphalt pavement, as evidenced by lower Marshall stability values. The results of the testing conducted indicated that, at the amounts of coating applied, the heavy application of the RPS material was most effective of the materials tested at preventing aging in asphalt Marshall specimens.

The evaluation of the material properties (penetration, viscosity, phase angle, and shear modulus) of the control cationic asphalt emulsion (CSS-1) and the RPS emulsion showed that the RPS emulsion was initially a softer asphalt material. The evaluation of aged scrub test specimens indicated that the material properties of the RPS emulsion did not change (harden) with aging as evidenced by the relatively consistent amount of aggregate loss regardless of the amount of aging. However, the cationic asphalt emulsion experienced a substantial decrease in the amount of aggregate loss with aging, indicating that it was probably experiencing substantial hardening with aging. This apparent resistance to hardening or aging of the RPS emulsion, when compared a standard emulsion, would indicate a major benefit in regard to durability.

The overall performance of the RPS emulsion in laboratory testing and visual observations from field visits would indicate that it should provide improved performance over standard asphalt emulsions when used as a seal coat material. 
The RPS emulsion may work as a fog seal; however, it would appear more reasonable to apply it in conjunction with an application of sand.

\section{Recommendations}

Evaluation of the RPS emulsion in field applications with the retention of a representative control section would provide invaluable direct evidence of the effectiveness of the material. Additional evaluation of the RPS emulsion with further laboratory evaluations would provide further information on the effectiveness of the material as a seal coat material. 


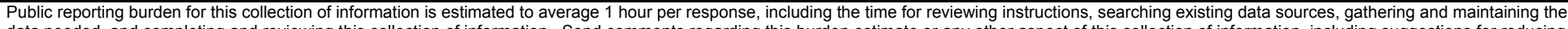

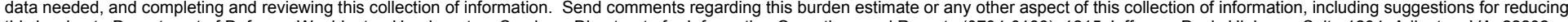

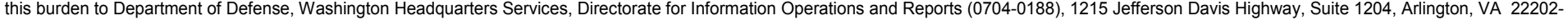

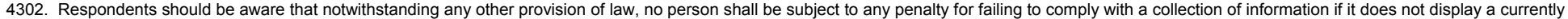
valid OMB control number. PLEASE DO NOT RETURN YOUR FORM TO THE ABOVE ADDRESS.

\begin{tabular}{l|l|l} 
1. REPORT DATE (DD-MM-YYYY) & 2. REPORT TYPE & 3. DATES COVERED (FrOm - To)
\end{tabular}

March 2003

4. TITLE AND SUBTITLE

Final report

Evaluation of Runway Preservation System

5a. CONTRACT NUMBER

5b. GRANT NUMBER

6. AUTHOR(S)

5c. PROGRAM ELEMENT NUMBER

James E. Shoenberger, J. Kent Newman

5d. PROJECT NUMBER

5e. TASK NUMBER

5f. WORK UNIT NUMBER

7. PERFORMING ORGANIZATION NAME(S) AND ADDRESS(ES) AND ADDRESS(ES)

8. PERFORMING ORGANIZATION REPORT NUMBER

U.S. Army Engineer Research and Development Center

Geotechnical and Structures Laboratory

ERDC/GSL SR-03-2

3909 Halls Ferry Road

Vicksburg, MS 39180-6199

9. SPONSORING / MONITORING AGENCY NAME(S) AND ADDRESS(ES)

10. SPONSOR/MONITOR'S ACRONYM(S)

Asphalt Systems, Inc.

2375 W. $1500 \mathrm{St}$.

P.O. Box 25511

Salt Lake City, UT 84125

11. SPONSOR/MONITOR'S REPORT NUMBER(S)

\section{DISTRIBUTION / AVAILABILITY STATEMENT}

Approved for public release, distribution is unlimited.

\section{SUPPLEMENTARY NOTES}

\section{ABSTRACT}

This report describes field and laboratory evaluation of an emulsified asphalt material "Runway Preservation System (RPS)," manufactured by Asphalt Systems, Inc., Salt Lake City, UT. A field application of this material was observed in Portland, OR. An evaluation of the RPS emulsion in regard to ability to seal a pavement surface in relation to other types of sealing indicated that a heavy application could retard the aging of the underlying surface. The durability of the RPS emulsion was compared to an asphalt emulsion by evaluating its ability to hold aggregate under abrasion. The results showed that the RPS emulsion did not appear to have a substantial change in properties with aging, indicating improved durability over the asphalt emulsion.

\section{SUBJECT TERMS}

Asphalt emulsions

Durability testing

Gilsonite

UNCLASSIFIED

\begin{tabular}{|c|c|c|c|c|c|}
\hline \multicolumn{3}{|c|}{ 16. SECURITY CLASSIFICATION OF: } & \multirow{2}{*}{$\begin{array}{l}\text { 17. LIMITATION } \\
\text { OF ABSTRACT }\end{array}$} & \multirow{2}{*}{$\begin{array}{l}\text { 18. NUMBER } \\
\text { OF PAGES }\end{array}$} & 19a. NAME OF RESPONSIBLE PERSON \\
\hline $\begin{array}{l}\text { a. REPORT } \\
\text { UNCLASSIFIED }\end{array}$ & $\begin{array}{l}\text { b. ABSTRACT } \\
\text { UNCLASSIFIED }\end{array}$ & $\begin{array}{l}\text { c. THIS PAGE } \\
\text { UNCLASSIFIED }\end{array}$ & & & $\begin{array}{l}\text { 19b. TELEPHONE NUMBER (include area } \\
\text { code) }\end{array}$ \\
\hline
\end{tabular}

\begin{tabular}{|c|c|c|c|c|c|}
\hline \multicolumn{3}{|c|}{ 16. SECURITY CLASSIFICATION OF: } & \multirow{2}{*}{$\begin{array}{l}\text { 17. LIMITATION } \\
\text { OF ABSTRACT }\end{array}$} & \multirow{2}{*}{$\begin{array}{l}\text { 18. NUMBER } \\
\text { OF PAGES } \\
26\end{array}$} & 19a. NAME OF RESPONSIBLE PERSON \\
\hline $\begin{array}{l}\text { a. REPORT } \\
\text { UNCLASSIFIED }\end{array}$ & $\begin{array}{l}\text { b. ABSTRACT } \\
\text { UNCLASSIFIED }\end{array}$ & $\begin{array}{l}\text { c. THIS PAGE } \\
\text { UNCLASSIFIED }\end{array}$ & & & $\begin{array}{l}\text { 19b. TELEPHONE NUMBER (include area } \\
\text { code) }\end{array}$ \\
\hline
\end{tabular}

Rheological testing

Seal coat 